\title{
Relationship between the Population Density of Phytophagous and Predaceous Mites Associated with Three Mango Varieties at Assiut and Sohag Governorates
}

Mahmoud, A.S. ${ }^{1}$; M.A.A. Abou-Shosha ${ }^{1}$; N.A. Mahmoud ${ }^{1}$ and A.A. Abd-Allah ${ }^{2}$

${ }^{1}$ Department of Agricultural Zoology and Nematology, Faculty of Agriculture, AlAzhar University, Assiut branch

${ }^{2}$ Department of Agricultural Zoology and Nematology Faculty of Agriculture, Al-Azhar University, Cairo

Email: Abuealhamd43@gmail.com

Received on: $7 / 10 / 2020$

Accepted for publication on: 12/10/2020

\section{Abstract}

The population densities of phytophagous and predaceous mites inhabiting leaves and green buds of three mango (Mangifera indica L.) varieties (Baladi, Hind and Taimour) were studied from April 2013 to March 2015. The experiments were carried out at four places at Assiut and Sohag governorates to determine the relationship between phytophagous mites and predaceous mites. Phytophagous mites Oligonychus mangiferus (Tetranychidae) and Cisaberoptus kenyae (Eriophyidae) inhabiting leaves of Baladi varieties were found with high density at Assiut and Sohag governorates, and they had two peaks during the year, the highest one was recorded in December month with mean numbers 894.00 individuals/25leaves in first year and 1004.25 individuals/25leaves in second year at Assiut governorate. During the same month, the peak recorded mean numbers was 513.75 individuals/25leaves at the first year, and 533.50 individuals/25leaves for the second year at Sohag governorate. Also phytophagous mites inhabiting leaves of the two varieties (Hind and Taimour) had two peaks, the first one recorded in July and the second recoded in January. While the peak of July month was the highest one it recorded average number $568.50 \& 657.00$ individual/25leaves in first and second years respectively for Hindi variety at Sohag, and 282.75 and 287.50 individual/25leaves in the two years respectively for Hindi variety at Assiut. The highest peak of Taimour variety was in July month with mean 577.50 and 670.75 individual at Sohag, while was in Jun at Assiut with mean 297.00 and 312 individual/25leaves during the first and second years, respectively. Predaceous mites (Amblyseius cucumeris and Typhlodromus mangiferus) associated with leaves of mango varieties during the two year were found with few number on leaves of mango varieties, and had a one peak in the year. The highest peak was recorded during June month with average numbers 69.25 individual in the first year (2013/2014) and 74.00 individuals/25leaves in the second year $(2014 / 2015)$ on leaves of Hindi variety at Assiut governorate. Phytophagous mites Aceria mangiferae and Metaculus mangiferae (Eriophyidae) inhabiting terminal and lateral buds of three mango verities were found with high numbers in the buds. Phytophagous mites inhabiting buds often had three peaks at the year, in May, August and November months. The highest peak was recorded on buds of Taimour variety with mean numbers 731.50 and 786.75 individuals $/ 5$ terminal buds and 458.75 and 384.00 individuals/5 lateral buds at May month in the first and second years respectively, at Sohag governorate. Predaceous mites Amblyseius cucumeris 
and Typhlodromus magnifiers (Phytoseiidae) associated with Buds of mango varieties were found with slightly numbers during warm months, but didn't recorded any number during December and January months. Predaceous mites inhabiting buds had one annual peak during July month. The highest peak was recorded on buds of Taimour variety with average 7.25 and 8.00 individual/5 terminal buds, and 7.00 and 7.50 individuals/5 lateral buds in the first and second years respectively, at Assiut governorate. Statistically, there was non-significant positive correlation between the population density of phytophagous mites and numbers of predatory mites during the two years, except some cases were significant positive correlation during the two years with Oligonychus mangiferus mite.

Keywords: Phytoseiidae, Tetranychidae, Eriophyidae, Population density, phytophagous mites.

\section{Introduction}

Mango fruits are a widely grown fruit trees throughout the tropical and subtropical regions, AlAzzazy, (2012). Mango fruits are one of the most important fruit in Egypt for local market or in exporting to the external markets. Phytophagous mites Oligonychus mangiferus and Cisaberoptus kenyae inhabiting leaves and phytophagous mites Aceria mangiferae and Metaculus mangiferae inhabiting buds are important pests of mango. Devi et al., (2017) studied the seasonal incidence of mango bud mite and found the mango bud mite was very low in both October, 2013 (3.7 and 4.3) and 2014 (2.4 and 1.8). The highest density of $O$. mangiferus was 7.9 mites/leaf on the second sampling date October 2008, Domingos et al., (2014). The population fluctuation of phytophagous mites $O$. mangiferae (Tetranychidae) on leaves and $M$. mangiferae (Eriophyidae) on buds of mango, had two annual peaks of seasonal abundance in May and November on different mango varieties in Giza Governorate, Abd-Allah (2008). The population density of phytophagous mite $O$. mangiferae on mango was reached to its highest population during early July in the two study sea- sons, whereas the predaceous mites Typhlodromus mangiferous, Agistemus exertus, Amblyseius swiriskii and Pronematus ubiquitus were found as predaceous mites, Fathy (2007). The mango pest (Aulacaspis tubercularis) had 3 peaks in the year, 2011. The first was recorded at May, the second was recorded at August while the third at November, Salem (2015). Ata et al., (2016) surveyed mite species inhabiting leaves and debris of two varieties of citrus (navel orange and mandarin) in Fayoum governorate, and data revealed the occurrence of 44 mite species, according to their feeding habits and systematic position. Joyce et al., (2020) surveyed five phytoseiid species on rosehip (Rosa canina L.) (Rosaceae) in Ankara, Turkey. So, present work was shed initiated to light on the influence of population densities of predaceous mites Amblyseius cucumeris and Typhlodromus mangiferus inhabiting mango trees on population densities of phytophagous mites $O$. mangiferus and $C$. kenyae infesting leaves and $A$. mangiferae and $M$. mangiferae infesting buds of mango trees.

Materials and Methods 1-Population density of mites: 
The population density of mites inhabiting mango (Mangifera indica L.) varieties (Baladi, Hind and Taimour) were recorded from April 2013 to March 2015. The experiments were carried out at four places at Assiut and Sohag governorates. Farm of Faculty of Agriculture Al-Azhar University, Assiut branch; local Farm at Sahel Selim, Assiut; and local farm at AlMaragha, Sohag and the last Farm of Shandaweel Agricultural Research Station, Sohag. Samples of 25 leaves, 5 lateral and 5 terminal buds of every variety replicated four times were collected weekly. The samples were examined in the laboratory as soon after collection by the aid of a stereomicroscope. Mite numbers on buds, upper and lower leaf surfaces were recorded.

\section{2-Statistical analysis of data:}

Correlation between the average of the population density of Phytophagous and Predaceous mites, also significance calculated regression was tested according to Steel and Torric, (1960).

\section{Results and Desiccation}

1- Population density of phytophagous mites (Oligonychus mangiferus and Cisaberoptus kenyae) and predaceous mites (Amblyseius cucumeris and Typhlodromus mangiferus) associated with leaves of mango varieties during two years (2013/2014 - 2014/2015):

\section{1- Mites inhabiting leaves of} mango variety Ballade at Sohag and Assiut governorate:

Tables (1 and 2) Shows that, the phytophagous mites hade two peaks during the two successive years on leaves of mango variety Baladi at Sohag governorate, the first peak was in August with average 544.25 and
555.00 individuals/25 leaves during the two years respectively. While the second peak was recorded in December with mean numbers 513.75 and 533.50 individuals during the two years respectively. Also, two peaks were recorded for phytophagous mites at Assiut governorate, the first one was in August with mean numbers 616.25 individuals in the first year, and 770.00 individuals/25 leaves in the second year, and the second peak was found in December with an average 894.00 and 1004.25 individuals/25 leaves during the two years respectively. However the predaceous mites A. cucumeris and T. mangiferus have one annual peaks of seasonal abundance, in Sohag was recorded in July with number 39.75 \& 42.75 individuals/25 leaves during the two successive years respectively. In Assiut the peak was in August with mean numbers 29.25 \& 29.00 individuals/25 leaves in the first and second year, respectively. The lowest numbers of phytophagous mites at Sohag were recorded in February with average $347.75 \& 373.00$ individuals followed by January with mean 377.00 and 387.75 individuals/25 leaves during the two successive years, respectively. The predaceous mites recorded zero number during January month at Sohag, while at Assiut recorded zero number during January and February during the two successive years. Also, data in Tables (1 and 2), show a highly significant positive effect on population density of Oligonychus mangiferus affected by the predaceous mite as, values $\left(0.929 * *, \quad 0.888^{* *}\right)$ and $\left(0.941^{* *}, 0.844^{* *}\right)$ were detected in the first and second years, in Sohag and Assiut respectively. 
Table 1. Monthly mean numbers of phytophagous and predaceous mites associated with mango variety Baladi on leaves during two years at Sohag Governorate

\begin{tabular}{|c|c|c|c|c|c|c|c|c|}
\hline \multirow[b]{3}{*}{ Months } & \multicolumn{8}{|c|}{ Mean no. of moving stages / 25 leaves } \\
\hline & \multicolumn{4}{|c|}{$2013 / 2014$} & \multicolumn{4}{|c|}{$2014 / 2015$} \\
\hline & $\begin{array}{c}O . \\
\text { mangiferus }\end{array}$ & $\begin{array}{c}\text { C. ken- } \\
\text { yae }\end{array}$ & $\begin{array}{l}\text { Total } \\
\text { No. of } \\
\text { phyto. } \\
\text { mites }\end{array}$ & $\begin{array}{l}\text { Total } \\
\text { No. of } \\
\text { pred. } \\
\text { mites }\end{array}$ & $\begin{array}{c}O . \\
\text { mangiferus }\end{array}$ & $\begin{array}{c}\text { C. ken- } \\
\text { yae }\end{array}$ & $\begin{array}{c}\text { Total } \\
\text { No. of } \\
\text { phyto. } \\
\text { mites }\end{array}$ & $\begin{array}{l}\text { Total } \\
\text { No. of } \\
\text { pred. } \\
\text { mites }\end{array}$ \\
\hline April & 62.25 & 416.00 & 478.25 & 14.50 & 72.00 & 434.75 & 506.75 & 16.50 \\
\hline May & 84.00 & 376.50 & 460.50 & 18.50 & 86.50 & 388.00 & 474.50 & 21.75 \\
\hline June & 102.50 & 309.00 & 411.50 & 22.75 & 112.00 & 335.25 & 447.25 & 26.50 \\
\hline July & 164.00 & 247.00 & 412.00 & 39.75 & 174.25 & 332.75 & 407.00 & 42.75 \\
\hline Aug. & 158.00 & 386.25 & 544.25 & 28.75 & 163.00 & 392.00 & 555.00 & 30.50 \\
\hline Sep. & 83.00 & 272.00 & 355.00 & 22.25 & 93.00 & 278.00 & 371.00 & 24.50 \\
\hline Oct. & 40.00 & 261.25 & 301.25 & 13.50 & 46.00 & 248.00 & 294.00 & 15.50 \\
\hline Nov. & 36.00 & 376.25 & 412.25 & 5.50 & 38.00 & 388.00 & 426.00 & 5.00 \\
\hline Dec. & 15.50 & 498.25 & 513.75 & 1.25 & 14.75 & 518.75 & 533.50 & 1.25 \\
\hline Jan. & 12.00 & 365.00 & 377.00 & 0.00 & 13.25 & 374.50 & 387.75 & 0.00 \\
\hline Feb. & 35.75 & 312.00 & 347.75 & 1.75 & 37.00 & 336.00 & 373.00 & 3.00 \\
\hline Mar. & 92.50 & 332.50 & 425.00 & 10.25 & 98.75 & 350.00 & 448.75 & 13.00 \\
\hline$(\mathbf{r})$ & $0.929^{* *}$ & -0.482 & 0.172 & & $0.941^{* *}$ & -0.532 & 0.099 & \\
\hline
\end{tabular}

Table 2. Monthly mean numbers of phytophagous and predaceous mites associated with mango variety Baladi on leaves during two years at Assiut Governorate

\begin{tabular}{|c|c|c|c|c|c|c|c|c|}
\hline \multirow[b]{3}{*}{ Months } & \multicolumn{8}{|c|}{ Mean no. of moving stages / 25 leaves } \\
\hline & \multicolumn{4}{|c|}{$2013 / 2014$} & \multicolumn{4}{|c|}{2014 / 2015} \\
\hline & $\begin{array}{c}O . \\
\text { mangiferus }\end{array}$ & $\begin{array}{c}\text { C. ken- } \\
\text { yae }\end{array}$ & $\begin{array}{l}\text { Total } \\
\text { No. of } \\
\text { phyto. } \\
\text { mites }\end{array}$ & $\begin{array}{l}\text { Total } \\
\text { No. of } \\
\text { pred. } \\
\text { mites }\end{array}$ & $\begin{array}{c}O . \\
\text { mangiferus }\end{array}$ & $\begin{array}{c}\text { C. ken- } \\
\text { yae }\end{array}$ & $\begin{array}{c}\text { Total } \\
\text { No. of } \\
\text { phyto. } \\
\text { mites }\end{array}$ & $\begin{array}{l}\text { Total } \\
\text { No. of } \\
\text { pred. } \\
\text { mites }\end{array}$ \\
\hline April & 68.25 & 435.50 & 503.75 & 6.25 & 77.50 & 588.25 & 665.75 & 4.25 \\
\hline May & 62.00 & 232.25 & 294.25 & 8.25 & 71.50 & 378.00 & 449.50 & 5.25 \\
\hline June & 108.75 & 227.50 & 336.25 & 15.25 & 96.00 & 292.00 & 388.00 & 9.00 \\
\hline July & 174.25 & 363.00 & 436.25 & 22.25 & 166.75 & 384.50 & 551.25 & 17.75 \\
\hline Aug. & 150.00 & 466.25 & 616.25 & 29.25 & 142.00 & 628.00 & 770.00 & 29.00 \\
\hline Sep. & 95.50 & 287.25 & 383.25 & 15.00 & 97.00 & 405.00 & 502.00 & 13.25 \\
\hline Oct. & 73.00 & 426.25 & 499.25 & 5.50 & 82.50 & 564.75 & 647.25 & 8.00 \\
\hline Nov. & 42.75 & 525.75 & 568.50 & 2.75 & 63.00 & 677.00 & 740.00 & 2.50 \\
\hline Dec. & 21.00 & 873.00 & 894.00 & 0.75 & 32.00 & 972.25 & 1004.25 & 0.75 \\
\hline Jan. & 15.50 & 470.50 & 486.00 & 0.00 & 16.75 & 610.00 & 626.75 & 0.00 \\
\hline Feb. & 56.00 & 293.50 & 349.50 & 0.00 & 55.25 & 352.00 & 407.25 & 0.00 \\
\hline Mar. & 103.50 & 362.25 & 465.75 & 4.50 & 97.75 & 495.00 & 592.75 & 3.50 \\
\hline (r) & $0.888^{* *}$ & -0.352 & -0.126 & & $0.844 * *$ & -0.176 & 0.014 & \\
\hline
\end{tabular}

$(* *)$ Correlation is significant at the 0.01 level.

Densites of phytoseiid mites population and that of the phytophagous mites (a mixed population of $O$. mangiferus and $C$. kenyae individuals) during the two successive years (Table 1and 2 ), had no significant effect $(0.172,-0.126)$ and $(0.099,0.014)$ during the two successive years respectively. There was no significant correlation between the population density of phytophagous mite and numbers of predatceous mites during the two years. 


\section{2- Mites inhabiting leaves of mango variety Hindi at Sohag and Assiut governorate:}

Tables (3 and 4) clearly demonstrated that, the predaceous mites $A$. cucumeris and T. mangiferus have one annual peak of seasonal abundance on leaves of Hindi mango variety. It was recorded in August at Sohag with mean numbers 29.50 individuals in the first year and 36.00 individuals/25 leaves in the second year,. In Assiut the peak of predaceous mites was recorded in June with mean numbers 69.25 and 74.00 individual during the two successive years (2013/2014 and 2014/2015). Statistical analysis of the data obtained from tables (3 and 4), illustrated that, the relationship between the populations of phytoseiid mites and $O$. mangiferus was highly significant positively in Sohag, but it's not significant positively in Assiut, its effected $\left(0.938^{* *}\right.$ and 0.564$)$ and $\left(0.953^{* *}\right.$ and 0.539 ) in the first and the second years in Sohag and Assiut respectively. However, the relationship between the population of phytoseiid mite and the eriophyid mite Cisaberoptus kenyae had negative effect during two years. As shown by correlation values, Correlation coefficient values were ($0.717 * *,-0.355)$ and $(-0.263,-0.356)$ in the first and the second year in Sohag and Assiut Governorates respectively. Then the relationship between density of phytoseiid mites population and that of the phytophagous mites (a mixed population of $(O$. mangiferus and $C$. kenyae individuals) during the two successive years had no significant effect $(0.124$ and 0.066 and 0.309 and 0.012 ) during the two successive years in Sohag and Assiut governorates, respectively. Numbers of phytophagous mites started in rise from April to reached the first peak at July with average 568.50 and 657.00 individuals/25 leaves in first and second years respectively at Sohag. The second peak was found at January with mean numbers 542.50 individuals in the first year and 625.00 individuals $/ 25$ leaves in the second year at the same governorate.

Table 3. Monthly mean numbers of phytophagous and predaceous mites associated with mango Hindi variety on leaves during two years at Sohag Governorate

\begin{tabular}{|c|c|c|c|c|c|c|c|c|}
\hline \multirow[b]{3}{*}{ Months } & \multicolumn{8}{|c|}{ Mean no. of moving stages / 25 leaves } \\
\hline & \multicolumn{4}{|c|}{2013 / 2014} & \multicolumn{4}{|c|}{$2014 / 2015$} \\
\hline & $\begin{array}{c}\text { O. } \\
\text { mangiferus }\end{array}$ & $\begin{array}{c}\text { C. } \\
\text { kenyae }\end{array}$ & $\begin{array}{c}\text { Total No. } \\
\text { of phyto. } \\
\text { mites }\end{array}$ & $\begin{array}{l}\text { Total } \\
\text { No. of } \\
\text { pred. } \\
\text { mites }\end{array}$ & $\begin{array}{c}\text { O. } \\
\text { mangiferus }\end{array}$ & $\begin{array}{c}\text { C. } \\
\text { kenyae }\end{array}$ & $\begin{array}{l}\text { Total } \\
\text { No. of } \\
\text { phyto. } \\
\text { mites }\end{array}$ & $\begin{array}{l}\text { Total } \\
\text { No. of } \\
\text { pred. } \\
\text { mites }\end{array}$ \\
\hline April & 91.75 & 388.00 & 479.75 & 11.00 & 110.75 & 394.75 & 505.50 & 13.00 \\
\hline May & 78.50 & 272.50 & 351.00 & 12.75 & 99.00 & 288.00 & 387.00 & 13.75 \\
\hline June & 114.00 & 280.00 & 394.00 & 20.75 & 122.00 & 365.25 & 487.25 & 21.00 \\
\hline July & 175.00 & 393.50 & 568.50 & 26.75 & 205.00 & 452.00 & 657.00 & 34.50 \\
\hline Aug. & 140.00 & 256.75 & 396.75 & 29.50 & 182.00 & 382.00 & 564.00 & 36.00 \\
\hline Sep. & 82.25 & 238.00 & 320.25 & 19.75 & 94.25 & 258.25 & 352.50 & 22.75 \\
\hline Oct. & 74.00 & 269.00 & 343.00 & 10.75 & 87.75 & 298.00 & 385.75 & 13.75 \\
\hline Nov. & 50.75 & 290.00 & 340.75 & 5.50 & 36.75 & 336.00 & 372.75 & 4.75 \\
\hline Dec. & 32.00 & 348.25 & 380.25 & 2.25 & 21.50 & 478.00 & 499.50 & 1.75 \\
\hline Jan. & 6.25 & 536.25 & 542.50 & 0.50 & 4.50 & 620.50 & 625.00 & 0.50 \\
\hline Feb. & 18.75 & 347.50 & 366.25 & 4.00 & 12.25 & 386.00 & 398.25 & 4.00 \\
\hline Mar. & 56.00 & 255.00 & 311.00 & 10.00 & 48.25 & 270.00 & 318.25 & 12.50 \\
\hline$(\mathbf{r})$ & $0.938 * *$ & $-0.717 * *$ & 0.124 & & $0.953 * *$ & -0.263 & 0.309 & \\
\hline
\end{tabular}


Table 4. Monthly mean numbers of phytophagous and predaceous mites associated with mango Hindi variety on leaves during two years at Assiut Governorate

\begin{tabular}{|c|c|c|c|c|c|c|c|c|}
\hline \multirow[b]{3}{*}{ Months } & \multicolumn{8}{|c|}{ Mean no. of moving stages / 25 leaves } \\
\hline & \multicolumn{4}{|c|}{$2013 / 2014$} & \multicolumn{4}{|c|}{$2014 / 2015$} \\
\hline & $\begin{array}{c}O . \\
\text { mangiferus }\end{array}$ & $\begin{array}{c}\text { C. ken- } \\
\text { yae }\end{array}$ & $\begin{array}{c}\text { Total } \\
\text { No. of } \\
\text { phyto. } \\
\text { mites }\end{array}$ & $\begin{array}{l}\text { Total } \\
\text { No. of } \\
\text { pred. } \\
\text { mites }\end{array}$ & $\begin{array}{c}O . \\
\text { mangiferus }\end{array}$ & $\begin{array}{c}\text { C. ken- } \\
\text { yae }\end{array}$ & $\begin{array}{c}\text { Total } \\
\text { No. of } \\
\text { phyto. } \\
\text { mites }\end{array}$ & $\begin{array}{l}\text { Total } \\
\text { No. of } \\
\text { pred. } \\
\text { mites }\end{array}$ \\
\hline April & 71.25 & 152.00 & 223.25 & 8.00 & 68.25 & 161.50 & 229.75 & 11.75 \\
\hline May & 57.50 & 68.00 & 125.50 & 21.00 & 55.25 & 72.00 & 127.25 & 22.50 \\
\hline June & 74.00 & 90.50 & 164.50 & 69.25 & 69.75 & 94.00 & 163.75 & 74.00 \\
\hline July & 117.00 & 96.25 & 213.25 & 65.75 & 107.50 & 102.25 & 209.75 & 67.25 \\
\hline Aug. & 134.25 & 148.50 & 282.75 & 23.50 & 126.75 & 160.75 & 287.50 & 27.75 \\
\hline Sep. & 98.50 & 31.00 & 129.50 & 23.50 & 96.50 & 32.00 & 128.50 & 23.75 \\
\hline Oct. & 46.25 & 61.25 & 107.50 & 18.25 & 61.25 & 70.50 & 131.75 & 19.00 \\
\hline Nov. & 28.00 & 88.00 & 116.00 & 0.50 & 34.25 & 96.00 & 130.25 & 1.50 \\
\hline Dec. & 20.75 & 132.75 & 153.50 & 1.00 & 27.50 & 140.50 & 168.00 & 0.50 \\
\hline Jan. & 10.50 & 228.00 & 238.50 & 2.75 & 12.25 & 232.50 & 244.75 & 3.00 \\
\hline Feb. & 23.50 & 164.00 & 187.50 & 5.00 & 32.50 & 176.25 & 208.75 & 6.00 \\
\hline Mar. & 90.75 & 103.75 & 194.50 & 6.25 & 94.25 & 115.00 & 209.25 & 9.00 \\
\hline (r) & 0.564 & -0.355 & 0.066 & & 0.539 & -0.356 & -0.012 & \\
\hline
\end{tabular}

(**) Correlation is significant at the 0.01 level.

The lowest number of phytophagous mites at Sohag was recorded at March in the two years with average 311.00 and 318.25 individuals in first and second years respectively. Phytophagous mites were approaches the same trend at Assiut governorate, that population of phytophagous mites had two peaks during the first and second years $(2013 / 2014$ and $2015 / 2015)$. The first peak was the highest one in August, with counts of 282.75 and 287.50 individuals $/ 25$ leaves in the two years, respectively. The second peak was recorded during January month with average numbers 238.50 and 244.75 individuals/25 leaves in the first and second years respectively at Assiut. On the other hand, lowest population in the first year was recorded at October with mean 107.50 individuals, while in the second year was in May with average numbers 127.25 individuals/25leaves at the same governorate.

\section{3- Mites inhabiting leaves of mango variety Taimour at So- hag and Assiut governorate: \\ Tables (5 and 6) explains that,} the predaceous mites (A. cucumeris and T. mangiferus) inhabiting mango variety Taimour had one annual peak of seasonal abundance, which was recorded in August during the two successive years with mean numbers 40.00 and 42.25 individuals/25 leaves at Sohag during the first and second years, respectively. At Assiut governorate the peak of predaceous mites was the highest one with mean numbers 54.00 and 60.75 individuals during the first and second years respectively. The lowest number of predaceous mites was recorded in January during the two years at the two governorates $(1.00 \& 0.25$ individual at Sohag and $0.00 \& 0.00$ individual at Assiut). A highly significant positive correlation existed between the predaceous mites populations and the 
mango red mite $O$. mangiferus in the first year $\left(0.798^{* *}, 0.712^{* *}\right)$, and the second year, $\left(0.792^{* *}, 0.724^{* *}\right)$. Such findings showed that, the predaceous mites positively effective on $O$. mangiferus mite. Concerning, statistical data obtained that, it was found the phytoseiid mites population were non-significant effect (-0.059, $0.654^{*}$ and $\left.-0.211,-0.661 *\right)$ on the population density of the leaf coat mango mite $C$. kenyae in the first and second year, respectively. Also, the relationship between the phytoseiid mite population density and the popu- lation density of total phytophagous mites ( $O$. mangiferus and $C$. kenyae) were non-significant effect $(0.369$ and -0.044 and 0.312 , and -0.077 ) during the two successive years. Phytophagous mites infesting mango variety Taimour were appear with highly numbers at Sohag and had two peaks during the two successive years. The first one recorded in July month with mean 577.50 and 670.75 individuals/25 leaves at Sohag during the first and second years respectively.

Table 5. Monthly mean numbers of phytophagous and predaceous mites associated with mango variety Taimour on leaves during two years at Sohag Governorate

\begin{tabular}{|c|c|c|c|c|c|c|c|c|}
\hline \multirow[b]{3}{*}{ Months } & \multicolumn{8}{|c|}{ Mean no. of moving stages / 25 leaves } \\
\hline & \multicolumn{4}{|c|}{$2013 / 2014$} & \multicolumn{4}{|c|}{$2014 / 2015$} \\
\hline & $\begin{array}{c}O . \\
\text { mangiferus }\end{array}$ & $\begin{array}{c}C . \\
\text { kenyae }\end{array}$ & $\begin{array}{c}\text { Total } \\
\text { No. of } \\
\text { phyto. } \\
\text { mites }\end{array}$ & $\begin{array}{c}\text { Total } \\
\text { No. of } \\
\text { pred. } \\
\text { mites }\end{array}$ & $\begin{array}{c}O . \\
\text { mangiferus }\end{array}$ & $\begin{array}{c}C . \\
\text { kenyae }\end{array}$ & $\begin{array}{c}\text { Total } \\
\text { No. of } \\
\text { phyto. } \\
\text { mites }\end{array}$ & $\begin{array}{l}\text { Total } \\
\text { No. of } \\
\text { pred. } \\
\text { mites }\end{array}$ \\
\hline April & 98.25 & 430.25 & 528.50 & 8.25 & 102.00 & 441.75 & 543.75 & 10.25 \\
\hline May & 77.00 & 298.00 & 375.00 & 11.25 & 84.50 & 301.50 & 386.00 & 15.75 \\
\hline June & 101.75 & 322.25 & 424.00 & 17.75 & 178.00 & 352.00 & 530.00 & 21.75 \\
\hline July & 206.50 & 371.00 & 577.50 & 28.25 & 284.75 & 386.00 & 670.75 & 30.50 \\
\hline Aug. & 152.00 & 418.50 & 570.50 & 40.00 & 172.00 & 457.00 & 629.00 & 42.25 \\
\hline Sep. & 80.50 & 290.00 & 370.50 & 27.75 & 95.00 & 278.00 & 373.00 & 27.00 \\
\hline Oct. & 40.00 & 237.00 & 277.00 & 15.00 & 61.25 & 244.00 & 305.25 & 16.50 \\
\hline Nov. & 28.50 & 202.75 & 231.25 & 8.75 & 42.00 & 228.25 & 270.25 & 7.25 \\
\hline Dec. & 22.00 & 363.00 & 385.00 & 3.25 & 28.00 & 395.00 & 423.00 & 4.75 \\
\hline Jan. & 18.00 & 512.25 & 530.25 & 1.00 & 22.25 & 590.50 & 612.75 & 0.25 \\
\hline Feb. & 20.25 & 382.00 & 402.25 & 3.00 & 27.00 & 479.00 & 506.00 & 3.50 \\
\hline Mar. & 54.00 & 294.00 & 348.00 & 6.75 & 61.50 & 396.00 & 457.50 & 8.25 \\
\hline (r) & $0.798 * *$ & -0.059 & 0.369 & & $0.792 * *$ & -0.211 & 0.312 & \\
\hline
\end{tabular}


Table 6. Monthly mean numbers of phytophagous and predaceous mites associated with leaves of mango variety Taimour during two years at Assiut Governorate

\begin{tabular}{|c|c|c|c|c|c|c|c|c|}
\hline \multirow[b]{3}{*}{ Months } & \multicolumn{8}{|c|}{ Mean no. of moving stages / 25 leaves } \\
\hline & \multicolumn{4}{|c|}{$2013 / 2014$} & \multicolumn{4}{|c|}{$2014 / 2015$} \\
\hline & $\begin{array}{c}\text { O. } \\
\text { mangiferus }\end{array}$ & $\begin{array}{c}\text { C. } \\
\text { kenyae }\end{array}$ & $\begin{array}{c}\text { Total } \\
\text { No. of } \\
\text { phyto. } \\
\text { mites }\end{array}$ & $\begin{array}{l}\text { Total } \\
\text { No. of } \\
\text { pred. } \\
\text { mites }\end{array}$ & $\begin{array}{c}\text { O. } \\
\text { mangiferus }\end{array}$ & $\begin{array}{c}\text { C. } \\
\text { kenyae }\end{array}$ & $\begin{array}{l}\text { Total } \\
\text { No. of } \\
\text { phyto. } \\
\text { mites }\end{array}$ & $\begin{array}{l}\text { Total } \\
\text { No. of } \\
\text { pred. } \\
\text { mites }\end{array}$ \\
\hline April & 51.75 & 143.00 & 194.75 & 7.75 & 57.00 & 152.00 & 209.00 & 9.75 \\
\hline May & 94.00 & 161.00 & 255.00 & 15.25 & 98.75 & 173.00 & 271.75 & 18.75 \\
\hline June & 102.00 & 195.00 & 297.00 & 26.75 & 110.00 & 202.00 & 312.00 & 28.75 \\
\hline July & 140.25 & 147.00 & 287.25 & 51.25 & 152.00 & 156.00 & 308.00 & 56.25 \\
\hline Aug. & 95.00 & 134.00 & 229.00 & 54.00 & 102.00 & 138.00 & 240.00 & 60.75 \\
\hline Sep. & 48.00 & 145.00 & 193.00 & 31.50 & 56.00 & 150.00 & 206.00 & 34.00 \\
\hline Oct. & 22.00 & 149.00 & 171.00 & 23.25 & 27.50 & 155.00 & 182.50 & 27.50 \\
\hline Nov. & 24.00 & 178.00 & 202.00 & 7.75 & 30.00 & 183.00 & 213.00 & 9.00 \\
\hline Dec. & 20.50 & 191.00 & 211.50 & 0.00 & 24.25 & 196.00 & 220.25 & 0.00 \\
\hline Jan. & 19.00 & 290.00 & 309.00 & 0.00 & 20.00 & 308.00 & 328.00 & 0.00 \\
\hline Feb. & 33.25 & 239.00 & 272.25 & 1.00 & 35.00 & 272.00 & 307.00 & 2.50 \\
\hline Mar. & 78.00 & 217.00 & 295.00 & 6.50 & 84.00 & 224.00 & 308.00 & 7.00 \\
\hline (r) & $0.712 * *$ & $-0.654 *$ & -0.044 & & $0.724 * *$ & $-0.661 *$ & -0.077 & \\
\hline
\end{tabular}

$(* *)$ Correlation is significant at the 0.01 level.

(*) Correlation is significant at the 0.05 level.

The second one recorded in January month with mean 530.25 and 612.75 individuals $/ 25$ leaves at Sohag during the first and second years respectively. Low numbers and low peaks for Phytophagous mites inhabiting leaves of mango variety taimour were recorded at Assiut governorate. The first peak was recorded in June month with average numbers 297.00 and 312 individuals $/ 25$ leaves at Assiut during the first and second years respectively, the second one was found in January month with mean 309.00 and 328.00 individuals during the first and second years respectively. Generally, the population density of phytoseiid mites were nonsignificant effect on population density of total phytophagous mites $(O$. mangiferus and $C$. kenyae), during the two successive years. But it high significant positive correlation was found between the phytoseiid mites and the tetranychid mite $O$. mangiferus. So, this results agree with those obtained by Al-Azzazy
(2005), Reis et al. (2008), AbdelMaksoud (2006), Fathy (2007) and Abd-Allah (2008).

2- The relationship between the population densities of phytophagous mites (Aceria mangiferae and Metaculus mangiferae) and predaceous mites (Amblyseius cucumeris and Typhlodromus mangiferus) associated with Buds mango varieties during two successive years (2013/2014 - 2014/2015):

2.1-Mites inhabiting buds of mango variety Baladi at Assiut and Sohag governorates.

Data in Tables (7 and 8) cleared that, the population of predaceous mites (A. cucumeris and $T$. mangiferus) inhabiting buds of mango variety Baladi have one annual peaks of seasonal abundance in June with mean numbers 4.00 and 5.00 individuals $/ 5$ terminal buds and $4.00,4.50$ individuals $/ 5$ lateral buds at Sohg during the first and second years respectively. 
Website: www.aun.edu.eg/faculty_agriculture/journals_issues_form.phpE-mail: ajas@aun.edu.eg

Table 7. Monthly mean numbers of phytophagous and predaceous mites associated with buds of mango Baladi variety during two years at Sohag Governorate

\begin{tabular}{|c|c|c|c|c|c|c|c|c|}
\hline \multirow{4}{*}{ Months } & \multicolumn{8}{|c|}{ Mean no. of phytophagous mites / 5 Buds } \\
\hline & \multicolumn{4}{|c|}{ Lateral buds } & \multicolumn{4}{|c|}{ Terminal buds } \\
\hline & \multicolumn{2}{|c|}{$2014 / 2015$} & \multicolumn{2}{|c|}{$2013 / 2014$} & \multicolumn{2}{|c|}{$2014 / 2015$} & \multicolumn{2}{|c|}{$2013 / 2014$} \\
\hline & $\begin{array}{r}\text { Phyto. } \\
\text { Mites }\end{array}$ & $\begin{array}{l}\text { Pred. } \\
\text { mites }\end{array}$ & $\begin{array}{c}\text { Phyto. } \\
\text { mites }\end{array}$ & $\begin{array}{l}\text { Pred. } \\
\text { mites }\end{array}$ & $\begin{array}{l}\text { Phyto. } \\
\text { Mites }\end{array}$ & $\begin{array}{l}\text { Pred. } \\
\text { mites }\end{array}$ & $\begin{array}{l}\text { Phyto. } \\
\text { Mites }\end{array}$ & $\begin{array}{l}\text { Pred. } \\
\text { mites }\end{array}$ \\
\hline April & 422.00 & 2.00 & 452.25 & 2.75 & 371.75 & 2.25 & 396.00 & 2.50 \\
\hline May & 614.50 & 3.25 & 658.00 & 3.75 & 580.25 & 3.00 & 612.50 & 3.50 \\
\hline June & 452.00 & 4.00 & 482.25 & 5.00 & 498.00 & 4.00 & 532.25 & 4.50 \\
\hline July & 390.25 & 3.25 & 504.00 & 4.00 & 426.75 & 2.00 & 470.75 & 3.25 \\
\hline Aug. & 560.75 & 2.25 & 618.75 & 2.75 & 320.25 & 1.50 & 398.00 & 1.75 \\
\hline Sep. & 346.00 & 1.25 & 372.00 & 1.25 & 105.00 & 0.75 & 216.50 & 0.75 \\
\hline Oct. & 208.25 & 0.00 & 240.75 & 0.00 & 52.00 & 0.00 & 40.25 & 0.00 \\
\hline Nov. & 300.00 & 0.00 & 348.00 & 0.00 & 238.00 & 0.00 & 280.75 & 0.00 \\
\hline Dec. & 452.75 & 0.00 & 480.75 & 0.00 & 378.75 & 0.00 & 409.00 & 0.00 \\
\hline Jan. & 271.00 & 0.00 & 372.50 & 0.00 & 295.25 & 0.00 & 311.25 & 0.00 \\
\hline Feb. & 232.50 & 0.50 & 302.00 & 1.25 & 176.25 & 0.75 & 232.50 & 1.50 \\
\hline Mar. & 418.50 & 2.75 & 345.00 & 2.75 & 258.50 & 2.25 & 270.00 & 2.50 \\
\hline (r) & \multicolumn{2}{|c|}{$0.611 *$} & \multicolumn{2}{|c|}{$0.614^{*}$} & \multicolumn{2}{|c|}{$0.709 * *$} & \multicolumn{2}{|c|}{$0.701 *$} \\
\hline
\end{tabular}

Table 8. Monthly mean numbers of phytophagous and predaceous mites associated with buds of mango Baladi variety during two years at Assiut Governorate

\begin{tabular}{|c|c|c|c|c|c|c|c|c|}
\hline \multirow{4}{*}{ Months } & \multicolumn{8}{|c|}{ Mean no. of phytophagous mites / 5 Buds } \\
\hline & \multicolumn{4}{|c|}{ Lateral buds } & \multicolumn{4}{|c|}{ Terminal buds } \\
\hline & \multicolumn{2}{|c|}{$2014 / 2015$} & \multicolumn{2}{|c|}{$2013 / 2014$} & \multicolumn{2}{|c|}{$2014 / 2015$} & \multicolumn{2}{|c|}{$2013 / 2014$} \\
\hline & $\begin{array}{r}\text { Phyto. } \\
\text { Mites }\end{array}$ & $\begin{array}{l}\text { Pred. } \\
\text { mites }\end{array}$ & $\begin{array}{l}\text { Phyto. } \\
\text { mites }\end{array}$ & $\begin{array}{l}\text { Pred. } \\
\text { mites }\end{array}$ & $\begin{array}{l}\text { Phyto. } \\
\text { Mites }\end{array}$ & $\begin{array}{l}\text { Pred. } \\
\text { mites }\end{array}$ & $\begin{array}{l}\text { Phyto. } \\
\text { Mites }\end{array}$ & $\begin{array}{l}\text { Pred. } \\
\text { mites }\end{array}$ \\
\hline April & 110.50 & 2.50 & 106.75 & 3.25 & 54.00 & 2.00 & 62.50 & 2.50 \\
\hline May & 480.00 & 3.00 & 512.00 & 3.75 & 326.25 & 2.50 & 334.75 & 3.00 \\
\hline June & 320.25 & 6.25 & 436.00 & 7.50 & 266.75 & 5.25 & 284.00 & 6.75 \\
\hline July & 180.00 & 5.00 & 252.00 & 6.75 & 224.00 & 4.50 & 196.00 & 5.50 \\
\hline Aug. & 392.75 & 4.25 & 365.25 & 5.75 & 238.50 & 3.00 & 224.75 & 4.50 \\
\hline Sep. & 200.50 & 3.00 & 196.00 & 4.00 & 110.00 & 1.75 & 106.00 & 3.00 \\
\hline Oct. & 457.00 & 2.25 & 422.50 & 2.75 & 266.25 & 0.75 & 259.50 & 1.75 \\
\hline Nov. & 380.00 & 1.00 & 366.25 & 1.50 & 198.75 & 0.50 & 186.00 & 0.75 \\
\hline Dec. & 260.00 & 0.00 & 275.00 & 0.75 & 132.75 & 0.00 & 140.00 & 0.50 \\
\hline Jan. & 200.00 & 0.00 & 206.00 & 0.00 & 102.00 & 0.00 & 115.00 & 0.00 \\
\hline Feb. & 180.50 & 1.50 & 192.00 & 2.25 & 90.00 & 0.75 & 96.00 & 1.50 \\
\hline Mar. & 140.50 & 2.50 & 154.00 & 2.75 & 69.25 & 2.00 & 73.25 & 2.50 \\
\hline (r) & \multicolumn{2}{|c|}{0.307} & \multicolumn{2}{|c|}{0.121} & \multicolumn{2}{|c|}{0.307} & \multicolumn{2}{|c|}{0.121} \\
\hline
\end{tabular}

$(* *)$ Correlation is significant at the 0.01 level.

(*) Correlation is significant at the 0.05 level.

Also, at Assiut governorate the peak of predaceous mites was recorded at June but with mean numbers $6.25,7.50$ individuals $/ 5$ terminal buds and 5.25 and 6.75 individuals $/ 5$ lateral buds in the first and second years, respectively. The months of Oct., Nov., Dec. and January recorded zero number for predaceous mites at Sohag, while in Assiut only in January month was recorded zero number for predaceous mites. 
Tables (7 and 8) showed that, a highly significant positive effect existed on population density of eriophyid mites affected by the predaceous mite as, values (0.614*, $\left.0.611^{*}\right)$ and $\left(0.701^{*}, 0.709^{* *}\right)$ were detected in the first and second year, on terminal and lateral buds in Sohag, respectively. Also, the phytoseiid mites population had negative effect on the population of eriophyid mites during two years. Whereas, correlation coefficient values $(0.121,0.307)$ and $(0.450,0.447)$ clearly showed that, no significant effect between population density of eriophyid mites and its predator mites in the first and second years, in Assiut respectively. The population of phytophagous mites (A. mangiferae and M. mangiferae) inhabiting terminal buds of mango variety Baladi at Sohag, had three peaks during the two years (2013/2014 and 2014/2015), the first peak was the highest one, it recorded during May month mean numbers $614.50 \& 658.00$ individuals $/ 5$ terminal buds, and the second peak was recorded during August month (560.75 \& 618.75 individuals/ 5 terminal buds), the third peak was the lowest, and occurred during December month $(452.75 \& 480.75$ individuals/5terminal buds) in the first and the second years respectively, at Sohag governorate. While, that population of phytophagous mites inhabiting lateral buds, had two peaks during the two years at the same governorate. The first peak occurred during May month with average 580.25 individuals for first year and 612.50 individuals/5 lateral buds in second year. The second peak was recorded at Dec. month with mean 378.75 in- dividuals in the first year and 409.00 individuals $/ 5$ lateral buds in second year at Sohag governorate. On the other hand, the population density of phytophagous mites inhabiting terminal and lateral buds had three peaks during the two years at Assiut governorate. The first peak observed during May with average 480.00 and 512 individuals $/ 5$ terminal buds in the first and second year, respectively. The second peak was recorded during August month with mean 392.75 individuals in the first year and 365.25 individuals for the second year. The last peak was recorded in October with mean 475.00 individuals in first year and 422.50 individuals $/ 5$ terminal buds in the second year. Also three peaks for phytophagous mites inhabiting lateral buds were recorded in the same months. The first one recorded in May month with average 326.25 and 334.75 individuals/5 lateral buds in the first and second year, respectively. The second peak was recorded during August month with mean 238.50 individuals in the first year and 224.75 individuals for the second year. The third peak was recorded in October with mean 266.25 individuals in first year and 259..50 individuals $/ 5$ lateral buds in the second year at Assiut governorate. Eriophyid mites recorded moderate numbers during the other months.

\section{2-Mites inhabiting buds of mango variety Hindi at Assiut and Sohag governorates.}

Tables (9 and 10) showed that, The predaceous mites (A. cucumeris and $T$. mangiferus) inhabiting terminal buds of mango variety Hindi didn't recorded any number during November, December and January months 
and starting to rise from February to reach a one annual peaks of seasonal abundance in July with mean numbers 5.75 and 6.25 individuals/5 buds during the two years at Sohag. Also, mites inhabiting terminal buds at Assiut had one peak in the same month (July) with mean numbers 5.00 and 5.50 individuals $/ 5$ buds during the two years, respectively. Predaceous mites (A. cucumeris and T. mangiferus) inhabiting lateral buds gradually increased after January month to reach a peak in July with average numbers 4.75 and 5.50 individuals $/ 5$ buds at Sohag, it was 4.25 and 5.00 individuals $/ 5$ buds at Assiut during the first and second years, respectively. Tables (9 and 10) showed that, no significant effect existed on population density of eriophyid mites affected by the predaceous mite as, values $(0.498$ and 0.558$)$ and (0.001 and 0.234) were detected in the first and second year, on terminal and lateral buds in Sohag, respectively. Whereas, Correlation coefficient values $(0.425,0.304)$ and $(0.492,0.456)$ clearly showed that, no significant between population density of eriophyid mites and its predator mites in the first and second year respectively, at Assiut. Numbers of phytophagous mites $(A$. mangiferae and $M$. mangiferae) inhabiting terminal buds of mango variety Hindi at Sohag, gradually increased from March reaching the first peak in May with average 508.75 and 590.25 individuals/ 5 buds, and the second peak was in November with average 413.50 and 443.50 individuals during the first and second years respectively.

Table 9. Monthly mean numbers of phytophagous and predaceous mites associated with buds of mango variety Hindi during two years at Sohag Governorate

\begin{tabular}{|c|c|c|c|c|c|c|c|c|}
\hline \multirow{4}{*}{ Months } & \multicolumn{8}{|c|}{ Mean no. of phytophagous mites / 5 Buds } \\
\hline & \multicolumn{4}{|c|}{ Lateral buds } & \multicolumn{4}{|c|}{ Terminal buds } \\
\hline & \multicolumn{2}{|c|}{$2014 / 2015$} & \multicolumn{2}{|c|}{$2013 / 2014$} & \multicolumn{2}{|c|}{$2014 / 2015$} & \multicolumn{2}{|c|}{$2013 / 2014$} \\
\hline & $\begin{array}{r}\text { Phyto. } \\
\text { Mites }\end{array}$ & $\begin{array}{l}\text { Pred. } \\
\text { mites }\end{array}$ & $\begin{array}{c}\text { Phyto. } \\
\text { mites }\end{array}$ & $\begin{array}{l}\text { Pred. } \\
\text { mites }\end{array}$ & $\begin{array}{l}\text { Phyto. } \\
\text { Mites }\end{array}$ & $\begin{array}{l}\text { Pred. } \\
\text { mites }\end{array}$ & $\begin{array}{l}\text { Phyto. } \\
\text { Mites }\end{array}$ & $\begin{array}{l}\text { Pred. } \\
\text { mites }\end{array}$ \\
\hline April & 340.25 & 2.00 & 401.00 & 2.50 & 138.00 & 2.50 & 192.00 & 2.75 \\
\hline May & 508.75 & 3.00 & 590.25 & 3.75 & 412.50 & 3.00 & 436.25 & 3.50 \\
\hline June & 454.25 & 5.00 & 506.75 & 4.75 & 207.75 & 3.50 & 233.00 & 4.00 \\
\hline July & 418.25 & 5.75 & 460.50 & 6.25 & 111.25 & 4.75 & 165.00 & 5.50 \\
\hline Aug. & 386.00 & 3.25 & 429.00 & 4.50 & 102.50 & 2.50 & 100.25 & 3.50 \\
\hline Sep. & 210.75 & 2.00 & 280.50 & 2.50 & 124.25 & 1.25 & 122.75 & 1.75 \\
\hline Oct. & 192.50 & 0.50 & 200.00 & 1.00 & 205.00 & 0.00 & 168.25 & 1.00 \\
\hline Nov. & 413.50 & 0.00 & 443.50 & 0.25 & 319.75 & 0.00 & 340.00 & 0.50 \\
\hline Dec. & 360.75 & 0.00 & 331.75 & 0.00 & 174.50 & 0.00 & 134.25 & 0.00 \\
\hline Jan. & 251.75 & 0.00 & 279.75 & 0.00 & 26.50 & 0.00 & 86.75 & 0.00 \\
\hline Feb. & 177.00 & 1.25 & 196.50 & 1.25 & 6.75 & 1.50 & 14.00 & 1.25 \\
\hline Mar. & 203.75 & 2.00 & 218.50 & 2.75 & 28.00 & 2.50 & 52.50 & 2.00 \\
\hline (r) & \multicolumn{2}{|c|}{0.558} & \multicolumn{2}{|c|}{0.498} & \multicolumn{2}{|c|}{0.234} & \multicolumn{2}{|c|}{0.001} \\
\hline
\end{tabular}


Table 10. Monthly mean numbers of phytophagous and predaceous mites associated with buds of mango Hindi variety during two years at Assiut Governorate

\begin{tabular}{|c|c|c|c|c|c|c|c|c|}
\hline \multirow{4}{*}{ Months } & \multicolumn{8}{|c|}{ Mean no. of phytophagous mites / 5 Buds } \\
\hline & \multicolumn{4}{|c|}{ Lateral buds } & \multicolumn{4}{|c|}{ Terminal buds } \\
\hline & \multicolumn{2}{|c|}{$2014 / 2015$} & \multicolumn{2}{|c|}{$2013 / 2014$} & \multicolumn{2}{|c|}{$2014 / 2015$} & \multicolumn{2}{|c|}{$2013 / 2014$} \\
\hline & $\begin{array}{r}\text { Phyto. } \\
\text { Mites }\end{array}$ & $\begin{array}{l}\text { Pred. } \\
\text { mites }\end{array}$ & $\begin{array}{c}\text { Phyto. } \\
\text { mites }\end{array}$ & $\begin{array}{l}\text { Pred. } \\
\text { mites }\end{array}$ & $\begin{array}{l}\text { Phyto. } \\
\text { Mites }\end{array}$ & $\begin{array}{l}\text { Pred. } \\
\text { mites }\end{array}$ & $\begin{array}{c}\text { Phyto. } \\
\text { Mites }\end{array}$ & $\begin{array}{l}\text { Pred. } \\
\text { mites }\end{array}$ \\
\hline April & 68.75 & 1.00 & 96.50 & 1.50 & 10.00 & 0.75 & 28.25 & 1.50 \\
\hline May & 152.00 & 1.75 & 194.00 & 2.25 & 58.25 & 1.75 & 95.75 & 2.25 \\
\hline June & 138.25 & 3.50 & 181.00 & 4.00 & 192.00 & 2.75 & 251.00 & 3.25 \\
\hline July & 242.00 & 5.00 & 278.00 & 5.50 & 284.00 & 4.25 & 385.25 & 5.00 \\
\hline Aug. & 328.50 & 4.00 & 360.50 & 3.25 & 196.00 & 2.75 & 208.00 & 2.75 \\
\hline Sep. & 176.00 & 2.50 & 282.00 & 2.50 & 100.75 & 1.50 & 146.50 & 1.25 \\
\hline Oct. & 90.50 & 1.75 & 103.00 & 1.75 & 20.00 & 0.75 & 42.00 & 0.50 \\
\hline Nov. & 174.00 & 0.50 & 185.00 & 0.50 & 98.50 & 0.50 & 118.00 & 0.25 \\
\hline Dec. & 285.00 & 0.00 & 342.00 & 0.00 & 214.00 & 0.00 & 288.75 & 0.00 \\
\hline Jan. & 98.00 & 0.00 & 178.00 & 0.00 & 190.75 & 0.00 & 239.00 & 0.00 \\
\hline Feb. & 57.25 & 0.75 & 85.00 & 0.50 & 102.00 & 0.25 & 142.50 & 0.50 \\
\hline Mar. & 26.00 & 1.50 & 44.00 & 1.50 & 34.25 & 1.00 & 62.00 & 1.50 \\
\hline (r) & \multicolumn{2}{|c|}{0.304} & \multicolumn{2}{|c|}{0.425} & \multicolumn{2}{|c|}{0.456} & \multicolumn{2}{|c|}{0.492} \\
\hline
\end{tabular}

Also phytophagous mites inhabiting lateral buds had two peaks during the two years; the first one was recorded in May with mean 412.50 and 436.25 individuals and the second one recorded in November with average 319.75 and 340.00 individuals/5 lateral buds during the first and second years respectively, at Sohag. On the other hand the eriophyid mites infested the terminal buds of mango variety Hindi at Assiut governorate had three peaks during the two years but with few numbers, the first one was recorded in May with mean 152.00 and 194.00 individuals and the second one recorded in August with average 328.50 and 360.50 individuals and the third one was in December with average numbers 285.00 and 342.00 individuals $/ 5$ terminal buds during the first and second years respectively. While eriophyid mites infested the lateral buds had only two peaks at the same governorate (Assiut); the first one was observed in July with mean 284.00 and
385.25 individuals and the second one recorded in December with average 214.00 and 288.75 individuals/5lateral buds during the first and second years respectively. The minimum recorded numbers for eriophyid mites infested the terminal buds at Assiut were in March with mean 26.00 and 44.00 individuals and at Sohag were in February with mean 177.00 and 196.50 individuals/5terminal buds during the first and second years respectively. Minimum recorded numbers for lateral buds were in February at Sohag with average $6.75 \& 14.00$ individuals. However at Assiut were in April with mean 10.00 and 28.25 individuals/5lateral buds during the first and second years, respectively.

\section{3- Mites inhabiting buds of mango variety Taimour at As- siut and Sohag governorates. \\ Tables (11 \& 12) illustrated that,} The predaceous mites (A. cucumeris and $T$. mangiferus) inhabiting buds of Taimour, started in increasing gradu- 
Website: www.aun.edu.eg/faculty_agriculture/journals_issues_form.phpE-mail:ajas@aun.edu.eg

ally from February to reach a peak in August with average 4.75 and 5.25 individuals/5terminal buds at Sohag, while the mites inhabiting lateral buds reach a peak at July with mean 3.75 and 4.2525 individuals $/ 5$ buds during the first and second years respectively. The population density of predaceous mites decreased gradually to reach zero number from November to February for terminal and lateral buds at Sohag governorate. The predaceous mites inhabiting buds at Assiut governorate also had one annual peaks of seasonal abundance at July with mean 7.25 and 8.00 individuals/5buds in case terminal buds and 7.00 and 7.50 individuals/5buds in case lateral bud in the two successive years respectively.

Table 11. Monthly mean numbers of phytophagous and predaceous mites associated with buds of mango Taimour variety during two years at Sohag Governorate

\begin{tabular}{|c|c|c|c|c|c|c|c|c|}
\hline \multirow{4}{*}{ Months } & \multicolumn{8}{|c|}{ Mean no. of phytophagous mites / 5 Buds } \\
\hline & \multicolumn{4}{|c|}{ Lateral buds } & \multicolumn{4}{|c|}{ Terminal buds } \\
\hline & \multicolumn{2}{|c|}{$2014 / 2015$} & \multicolumn{2}{|c|}{$2013 / 2014$} & \multicolumn{2}{|c|}{$2014 / 2015$} & \multicolumn{2}{|c|}{$2013 / 2014$} \\
\hline & $\begin{array}{l}\text { Phyto. } \\
\text { Mites }\end{array}$ & $\begin{array}{l}\text { Pred. } \\
\text { mites }\end{array}$ & $\begin{array}{c}\text { Phyto. } \\
\text { mites }\end{array}$ & $\begin{array}{l}\text { Pred. } \\
\text { mites }\end{array}$ & $\begin{array}{l}\text { Phyto. } \\
\text { Mites }\end{array}$ & $\begin{array}{l}\text { Pred. } \\
\text { mites }\end{array}$ & $\begin{array}{l}\text { Phyto. } \\
\text { Mites }\end{array}$ & $\begin{array}{l}\text { Pred. } \\
\text { mites }\end{array}$ \\
\hline April & 475.75 & 2.00 & 426.50 & 2.25 & 309.00 & 2.00 & 312.00 & 2.25 \\
\hline May & 741.50 & 2.75 & 786.75 & 3.00 & 458.75 & 2.75 & 484.00 & 3.25 \\
\hline June & 634.00 & 3.50 & 668.00 & 4.00 & 294.25 & 3.25 & 356.50 & 3.75 \\
\hline July & 522.00 & 4.50 & 590.00 & 5.00 & 201.50 & 3.75 & 232.50 & 4.25 \\
\hline Aug. & 390.00 & 4.75 & 362.25 & 5.25 & 184.25 & 3.50 & 176.25 & 3.75 \\
\hline Sep. & 150.75 & 2.00 & 178.00 & 2.75 & 90.75 & 1.75 & 99.00 & 1.50 \\
\hline Oct. & 271.50 & 1.00 & 284.25 & 0.75 & 162.00 & 1.00 & 180.50 & 1.25 \\
\hline Nov. & 442.00 & 0.00 & 492.50 & 0.00 & 306.50 & 0.00 & 362.50 & 0.00 \\
\hline Dec. & 318.25 & 0.00 & 322.75 & 0.00 & 198.50 & 0.00 & 256.00 & 0.00 \\
\hline Jan. & 246.00 & 0.00 & 186.00 & 0.00 & 102.00 & 0.00 & 170.00 & 0.00 \\
\hline Feb. & 185.50 & 0.75 & 192.00 & 0.75 & 98.75 & 0.25 & 100.25 & 0.75 \\
\hline Mar. & 332.25 & 2.00 & 348.75 & 2.00 & 121.25 & 1.25 & 154.00 & 1.75 \\
\hline (r) & \multicolumn{2}{|c|}{0.484} & \multicolumn{2}{|c|}{0.512} & \multicolumn{2}{|c|}{0.282} & \multicolumn{2}{|c|}{0.357} \\
\hline
\end{tabular}

Table 12. Monthly mean numbers of phytophagous and predaceous mites associated with buds of mango Taimour variety during two years at Assiut Governorate

\begin{tabular}{|c|c|c|c|c|c|c|c|c|}
\hline \multirow{4}{*}{ Months } & \multicolumn{8}{|c|}{ Mean no. of phytophagous mites/5 Buds } \\
\hline & \multicolumn{4}{|c|}{ Lateral buds } & \multicolumn{4}{|c|}{ Terminal buds } \\
\hline & \multicolumn{2}{|c|}{$2014 / 2015$} & \multicolumn{2}{|c|}{$2013 / 2014$} & \multicolumn{2}{|c|}{$2014 / 2015$} & \multicolumn{2}{|c|}{$2013 / 2014$} \\
\hline & $\begin{array}{r}\text { Phyto. } \\
\text { Mites }\end{array}$ & $\begin{array}{l}\text { Pred. } \\
\text { mites }\end{array}$ & $\begin{array}{c}\text { Phyto. } \\
\text { mites }\end{array}$ & $\begin{array}{l}\text { Pred. } \\
\text { mites }\end{array}$ & $\begin{array}{l}\text { Phyto. } \\
\text { Mites }\end{array}$ & $\begin{array}{l}\text { Pred. } \\
\text { mites }\end{array}$ & $\begin{array}{c}\text { Phyto. } \\
\text { Mites }\end{array}$ & $\begin{array}{l}\text { Pred. } \\
\text { mites }\end{array}$ \\
\hline April & 498.75 & 2.50 & 514.75 & 3.25 & 196.00 & 2.75 & 226.00 & 3.00 \\
\hline May & 596.00 & 3.50 & 610.00 & 4.00 & 385.75 & 3.75 & 412.00 & 3.75 \\
\hline June & 385.00 & 5.50 & 400.00 & 6.25 & 280.00 & 4.75 & 306.50 & 5.25 \\
\hline July & 298.25 & 7.25 & 317.00 & 8.00 & 125.00 & 7.00 & 168.75 & 7.50 \\
\hline Aug. & 410.25 & 4.75 & 473.00 & 5.75 & 320.75 & 3.75 & 395.75 & 4.25 \\
\hline Sep. & 201.00 & 2.75 & 218.00 & 3.50 & 130.00 & 2.00 & 160.25 & 2.75 \\
\hline Oct. & 362.50 & 0.75 & 325.25 & 2.25 & 134.00 & 0.75 & 121.00 & 1.75 \\
\hline Nov. & 524.00 & 0.00 & 536.50 & 0.00 & 260.25 & 0.00 & 284.50 & 0.00 \\
\hline Dec. & 456.75 & 0.00 & 447.75 & 0.00 & 173.50 & 0.00 & 176.50 & 0.00 \\
\hline Jan. & 317.00 & 0.00 & 308.25 & 0.00 & 124.00 & 0.00 & 151.00 & 0.00 \\
\hline Feb. & 224.00 & 1.75 & 238.50 & 2.25 & 162.50 & 1.50 & 146.00 & 2.50 \\
\hline Mar. & 286.00 & 2.75 & 314.00 & 3.50 & 137.00 & 2.50 & 153.75 & 3.00 \\
\hline (r) & \multicolumn{2}{|c|}{-0.129} & \multicolumn{2}{|c|}{-0.054} & \multicolumn{2}{|c|}{0.072} & \multicolumn{2}{|c|}{0.099} \\
\hline
\end{tabular}


Tables (11 and 12) explained that, no significant effect existed on population density of eriophyid mites affected by the predaceous mites as, values $(0.512,0.484)$ and $(0.357$, 0.282 ) were obtained in the first and second year, on terminal and lateral buds in Sohag, respectively. Also, the phytoseiid mites populations had no significant effect on the population of Eriophyid mites during two years whereas, Correlation coefficient values $(-0.129,-0.054)$ and $(0.072,0.099)$ clearly showed that, no significant effect between population density of eriophyid mites and its predator mites in the first and second year, at Assiut respectively.

Tables (11 and 12) demonstrated that, the population of phytophagous mites inhabiting buds of mango variety Taimour at Sohag governorate had two peaks during the two years for terminal and lateral buds. The first was the highly one, it recorded in May month with average numbers 741.50 and 786.75 individuals for terminal buds and 458.75 and 484.00 individuals for lateral buds, and the second one was in November month with average numbers 442.00 and 492.50 individuals for terminal buds and 306.50 \& 362.50 individuals/5 lateral buds during the first and second years respectively, at Sohag. On the other hand the phytophagous mites inhabiting buds of mango variety Taimour at Assiut governorate had three peaks during the two years for terminal and lateral buds. The first was in May month with average numbers 596.00 and 610.00 individuals for terminal buds and 385 and 412.00 individuals for lateral buds, and the second one was in August month with moderate density 410.25 and
473.00 individuals for terminal buds and 320.75 and 395.75 individuals for lateral buds. The third peak recorded in November with average 524.00 and 536.50 individuals for terminal buds and $260.25 \& 284.50$ individuals/5 lateral buds during the first and second years respectively, at Assiut. Statistically, there was non-significant positive correlation between the population density of phytophagous mites and number of predatory mites during the two years, except Baladi mango variety in Sohag governorate was significant positive correlation during the two years; in addition to terminal bud of Taimour mango variety in Assiut was non- significant negative correlation during the two years. These results were agree with those obtained by AlAzzazy(2005), Abdelallah (2008) and Al-Azzazy (2016).

\section{References}

Abd-Allah, A.A.M. (2008). Susceptibility of mango varieties for infestation with mites. Ph.D. Thesis Fac. Agric., Al-Azhar University.

Abdel-Maksoud, M.A.(2006). Ecological and biological studies on mites associated with fruit trees in Assiut and Sohag Governorates.[PhD Thesis]. Cairo (Egypt): Al-Azhar University.

Al-Azzazy, M.M.,(2012). Mango Rust Mite Metaculus mangiferae (Attiah) (Acari: Eriophyidae) as Main Factor Affecting The Leaf Mineral Content of The Mango Trees Mangiferae indica L. J. Plant Prot. and Path., Mansoura Univ. 3 (10): $1099-1104$.

Al-Azzazy, M.M., (2005). Integrated management of mites infesting mango trees [PhD Thesis]. Cairo (Egypt): Al-Azhar University.

Al-Azzazy, M.M., (2016). Population fluctuation and control of the citrus 
rust mite, Phyllocoptruta olievora (Ashmead) (Arachnida: Prostigmata: Eriophyidae). Journal of Agricultural and Veterinary Sciences Qassim University, 9 (2): 175-186.

Ata, M.M.; Sakkran T.H.F., Fawzy M.M.H. and El-Shahawy G.Z., (2016). Survey and Population Dynamic of Some Mites Associated with Citrus Trees in Fayoum Governorate. Egypt. J. Agric. Res., 94 (1): 1-16.

Devi M.; Niranjana, R.F. and Umapathy, G. (2017). Seasonal incidence of different Aceria sp. correlated with weather parameters. Jour. of Entom. and Zoo. Studies; 5(3): 39-43.

Domingos, C.A.; Melo, J.W.S.; Oliveira, J.E.M. and Manoel, G.C. Gondim J.R., (2014). Mites on grapevines in northeast Brazil: occurrence, population dynamics and withinplant distribution, Inter. Jour. of Acarol. 10 (March) DOI: 10.1080/ 01647954.2014.891651.
Fathy, F.M.M. (2007). Environmental and Biological studies on some mites associated with the dominant and Widely distributed plants around Quaroun Lake areaFayoum Governorate. [M.Sc. Thesis] Ain shams university.

Joyce, M.R., Jaqueline M.P. Rodrigo D.D. and André J.A.P., (2020). Population Dynamics of Rubber Tree Mites. Floresta Ambiente; 27 (4):1-6.

Salem, H.A., Mahmoud Y.A. and Ebadah I.M.A., (2015). Seasonal Abundance, Number of Generations and Associated Injuries of the White Mango Scale, Aulacaspis tubercularis (Mangifera) (Newstead) (Homoptera: Diaspididae) Attacking Mango Orchards. JulyAugust 2015 RJPBCS 6(4):1379.

Steel, R.G.D. and Torrie, J.H., (1960). Principles and procedures of statistics. McGraw-Hill Book Company, INC. New York. 
العلاقة بين الكثافة العددية للأكاروسات نباتية التغذية والأكاروسات المفترسة المصاحبة لثلاثة

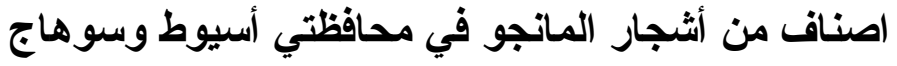

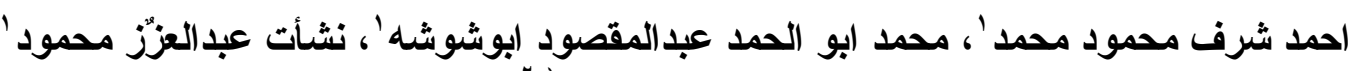
وعوض على عبدالله

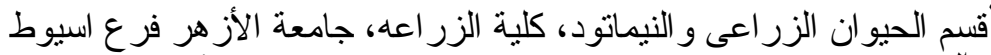

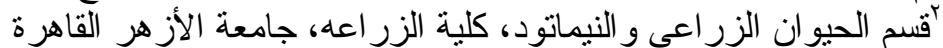

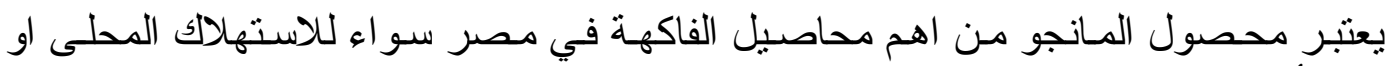

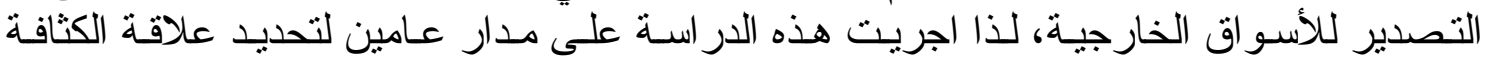

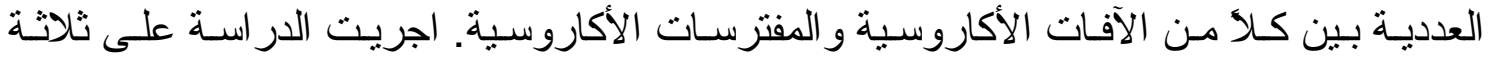

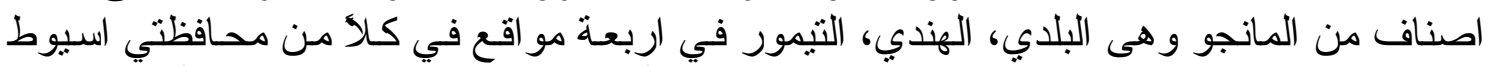

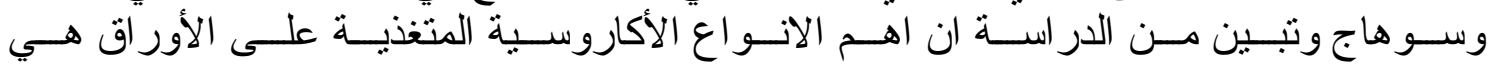
Cisaberoptus kenyae keifer gOligonychus mangiferus Rahman and Sapra

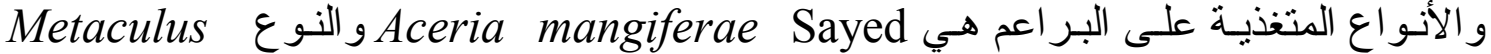
mangiferae Attiah في كلا من المحافظتنين و على الثلاثة اصناف. بينما الأكاروسات المفترسة

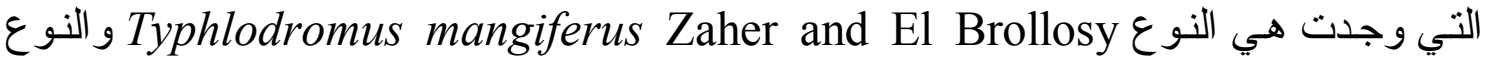
وتبين من الدر اسـة ان تذبذب اعداد الأكاروسـات

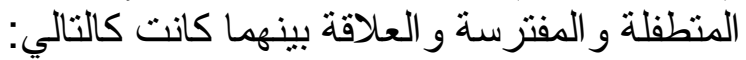

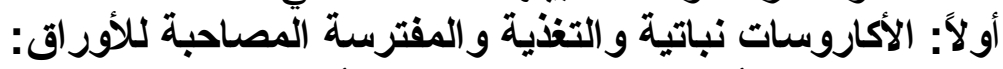

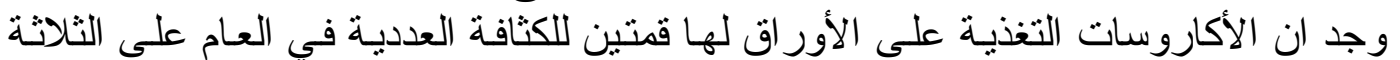

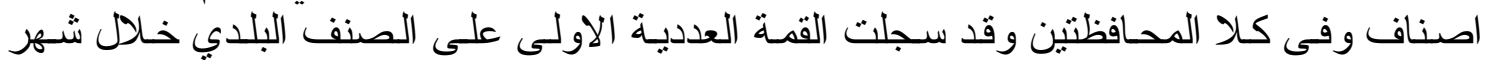

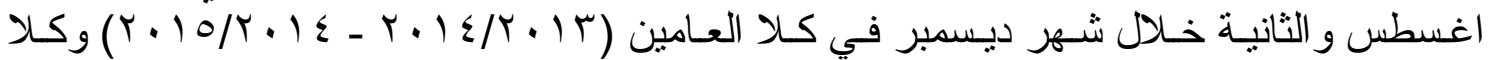

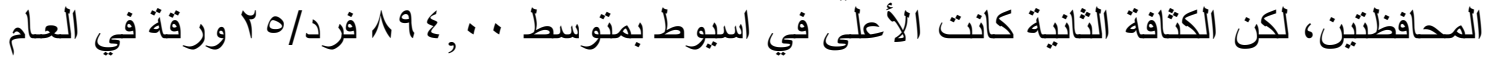

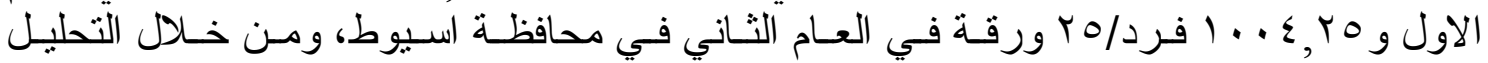

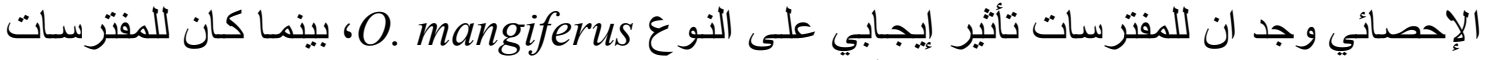

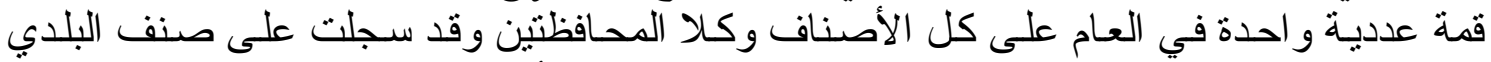

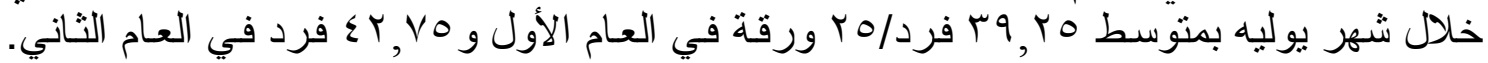

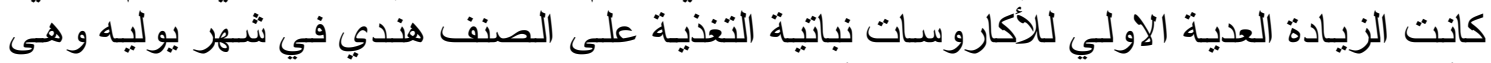

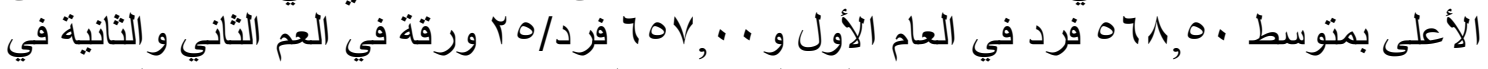

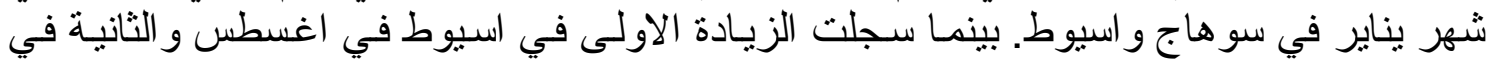

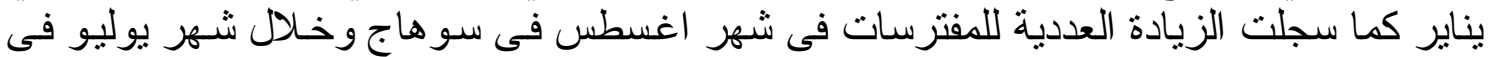

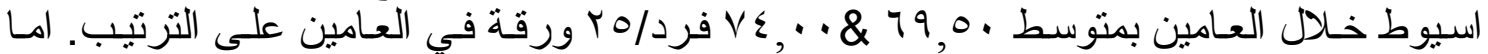

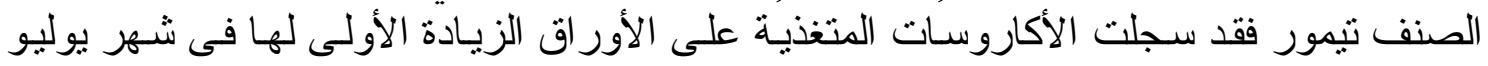

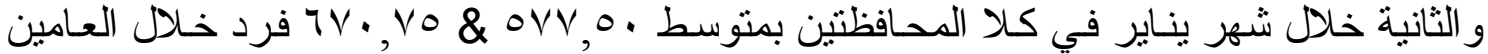

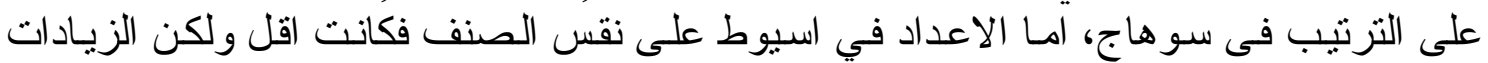

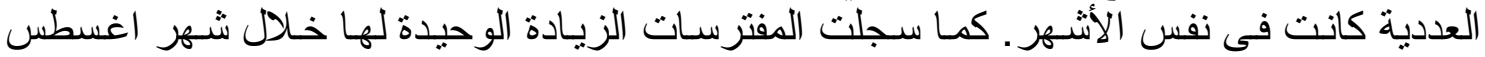

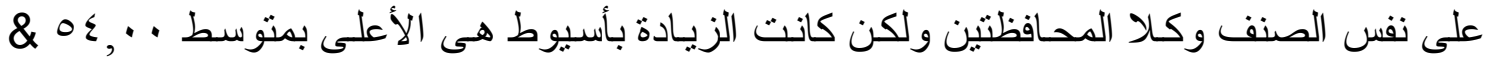

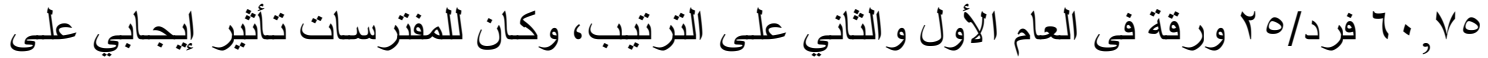
الأكاروسات المتغذية على الأور اق. 


\section{ثثاتياً: الأكاروسات نباتية التغذية والمفترسة المصاحبة للبر اعم: الماتية}

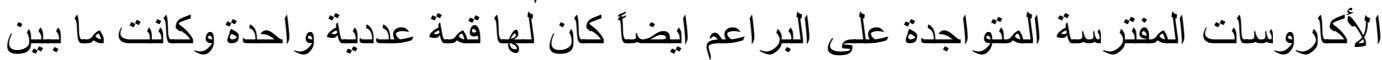

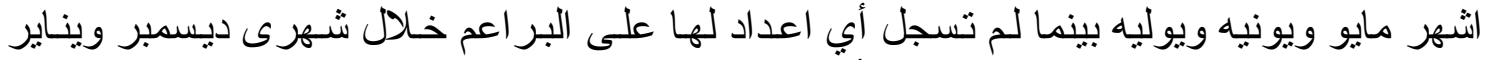

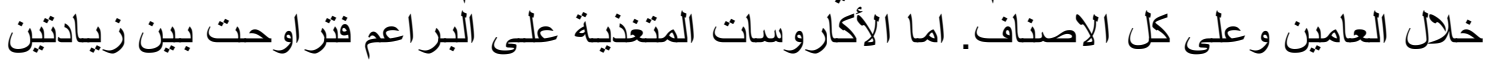

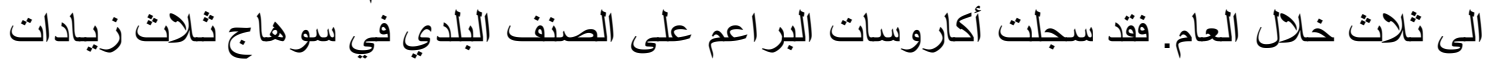

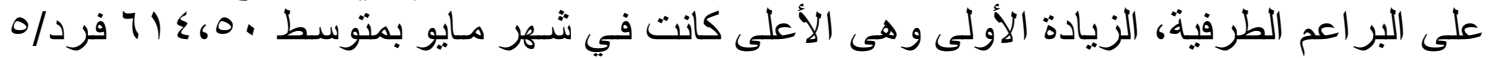

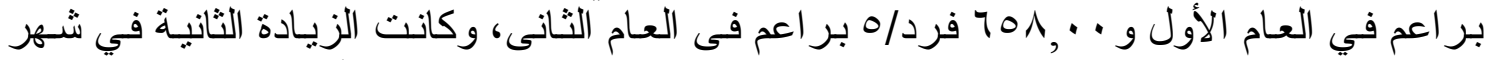

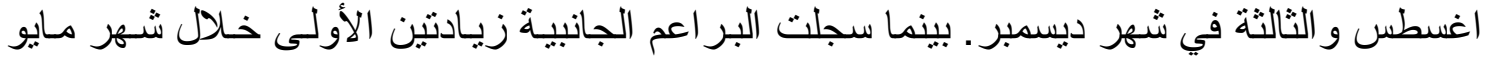

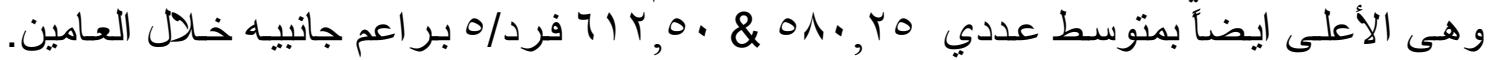

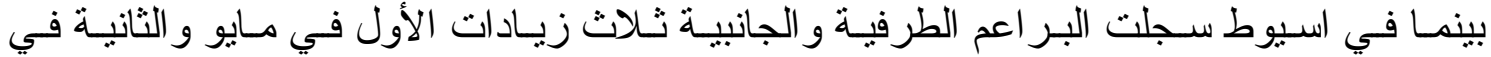

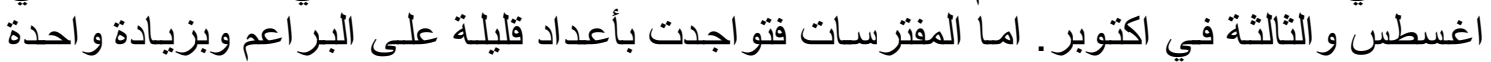

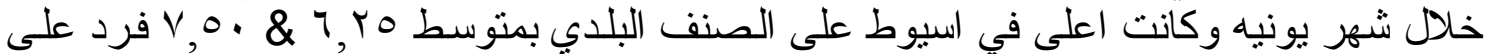

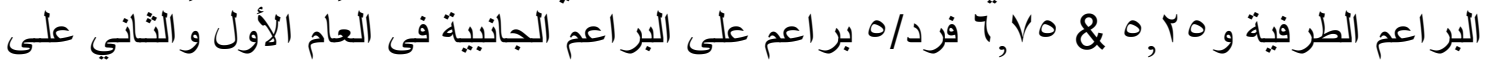

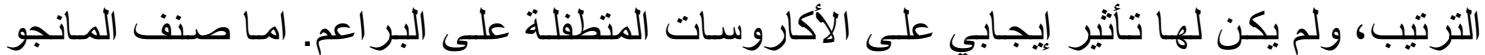

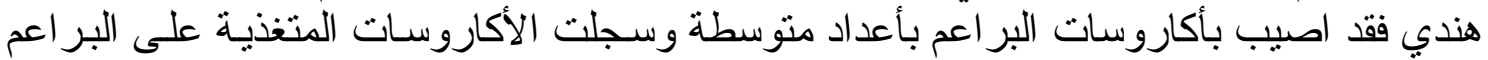

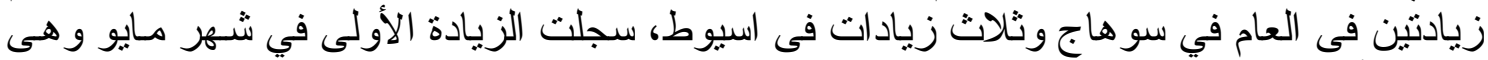

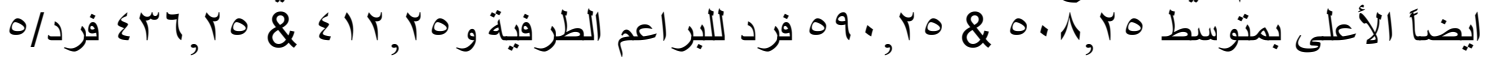

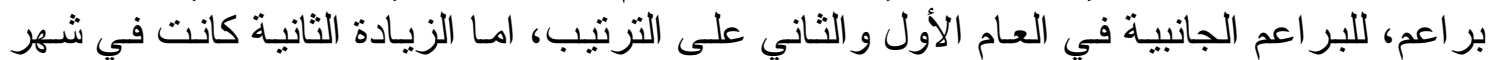

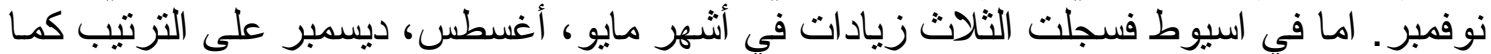

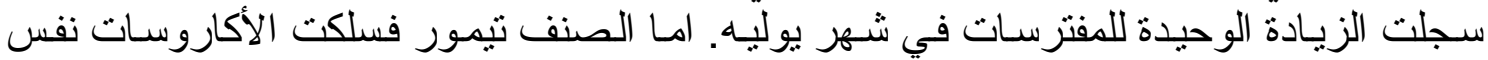
السلوك وهى زيادتين فى سوهاج الاول فى مايو و الثانية فى نوفمبر لكن بأعداد اعلى قليّلا، ايضاً

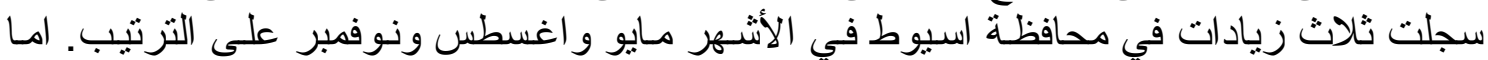

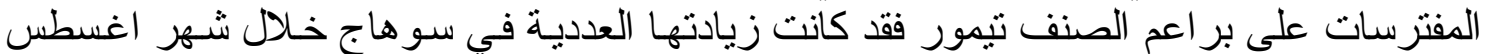

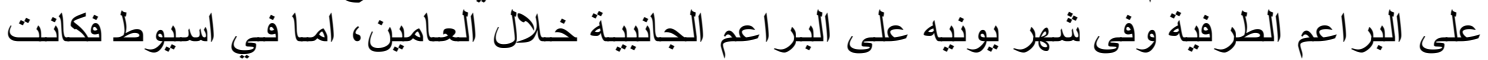
الزيادة العددية لها في يونيه على كلا من البر اعم الطرفية و الجانبية وفى العامين على التو التي. 